\title{
Prevalence of colonisation with vancomycin-resistant enterococci on admission - a cross-sectional study in 6 German university hospitals, 2014
}

\author{
M Wiese-Possselt ${ }^{*}$, J Zweígner ${ }^{2}$, AM Rohde ${ }^{3}$, F Schwab $^{3}$, W Kern ${ }^{4}$, H Seifert $^{2}$, P Gastmeier ${ }^{3}$, \\ the DZIF-ATHOS Study Group
}

From 3rd International Conference on Prevention and Infection Control (ICPIC 2015)

Geneva, Switzerland. 16-19 June 2015

\section{Introduction}

The survey presented here is part of the multicenter study ATHOS (antibiotic therapy optimisation study) on prevalence and incidence of nosocomial carriage of multi-drug resistant organisms (MDROs) in Germany.

\section{Objectives}

The aim of this survey was to assess the prevalence of rectal colonisation with VRE in patients on hospital admission. Additionally, we performed a risk factor analysis for VRE carriage.

\section{Methods}

We recruited adult patients within $72 \mathrm{~h}$ after admission to non-intensive care units in six German university hospitals to obtain rectal swabs that were screened for VRE. Each patient was asked to answer a short questionnaire on potential risk factors for colonisation with MDROs, such as sex, age, antibiotic therapy in the last 6 months, previous colonisation with any MDRO, travel abroad in the last 6 months, stay in a nursing home or hospitalisation in the last 6 months. Univariable and multivariable risk factor analyses were performed to identify those factors which were associated with VRE colonisation.

\section{Results}

In 2014, 4372 patients were included in the admission survey. Overall, 35 patients were colonised with VRE (admission prevalence of $0.8 \%$ ). The following factors were associated significantly with VRE carriage: centre (OR = 3.61, CI 95\% 3.05-4.27, $\mathrm{p}<0.001)$, previous MDRO colonisation $(\mathrm{OR}=3.23$, CI 95\% 1.47-7.11, $\mathrm{p}=0.004)$, antibiotic use $(\mathrm{OR}=2.91, \mathrm{CI} 95 \% 1.47-5.74, \mathrm{p}=0.002)$, stay in a nursing home $(\mathrm{OR}=3.19$, CI 95\% 1.87-5.46, $\mathrm{p}<0.001)$, and hospitalisation $(\mathrm{OR}=3.19, \mathrm{CI} 95 \% 2.06-5.42, \mathrm{p}=0.000)$. Interestingly, travel abroad had a protective effect on VRE carriage $(\mathrm{OR}=0.51, \mathrm{CI} 95 \%$ 0.29-0.91, $\mathrm{p}<0.001)$.

\section{Conclusion}

This admission survey in Germany revealed a moderate colonisation rate of $0.8 \%$, whereat prevalence differed significantly by centre. Well-known risk factors for VRE carriage were identified: previous colonisation with any MDRO, antibiotic use in the last 6 months, and admission to nursing homes or hospitals in the last 6 months. We observed that not travelling abroad was significantly associated with VRE carriage which we cannot explain. Thus, we cannot exclude a confounding factor we have not considered so far and should be addressed in further studies.

\section{Disclosure of interest}

None declared.

\footnotetext{
Authors' details

${ }^{1}$ Institute of Hospital Hygiene, Charité, Berlin, Germany. ${ }^{2}$ University Hospital Cologne, Germany. ${ }^{3}$ Charité, Germany. ${ }^{4}$ University Hospital Freiburg, Germany.
} 
Submit your next manuscript to BioMed Central and take full advantage of:

- Convenient online submission

- Thorough peer review

- No space constraints or color figure charges

- Immediate publication on acceptance

- Inclusion in PubMed, CAS, Scopus and Google Scholar

- Research which is freely available for redistribution

Submit your manuscript at www.biomedcentral.com/submit
C Biomed Central 